\title{
Historical Duration of Base Triangulation Network of Turkey
}

\author{
Nihat Ersoy \\ Yildiz Technical University, Civil Engineering Faculty, \\ Surveying Engineering Department \\ Davutpasa Campus, Esenler-Istanbul, Turkey \\ E-mail: ersoy@yildiz.edu.tr
}

\begin{abstract}
After establishing National Horizontal and Vertical Control Networks and Turkish National Fundamental GPS Network (TUTGA) for Turkey's geodetic infrastructure, governmental institutes that produce maps and map info like HGK (General Command of Mapping), TKGM (General Directorate of Land Registration and Cadastral of Turkey) and IKU (Istanbul Kultur University) established CORS-TR system in order to execute Turkey's defensive, developmental and scientific works with technological developments. CORS-TR, that has 146 permanent GPS stations across Turkey, enables users to calculate Real Time Kinematic positions with correction data. Therefore, in Turkey, mapping facilities are being done more rapidly, more economically and more easily.
\end{abstract}

Keywords: TUTGA, CORS-TR, GNSS, ED50, ITRF96, TUT54, TC-91, GRS80, TG-99, OPUS.

DOI: $10.7176 / \mathrm{JSTR} / 5-2-23$

\section{INTRODUCTION}

HGK achieved to set up Turkish National Geodetic Network (TNGN) between 1950-1954. Until 2001, all maps were produced on ED-50 datum across the country. Since the precision of TNGN whose coordinates were calculated on ED-50 is not adequate according to the level that modern technology reaches, HGK set up TUTGA network that consists of 594 points between 1997-2001 (Eren et.all (2009)).

CORS-TR, which consists of 146 points, was set up by HGK, TKGM and IKU between 2007 and 2011, and it is connected to TUTGA network that contains GNSS network (IKKU 2010).

CORS-TR network was set up for the purpose of determining real time, economic and precise geographical coordinates with 7/24 time principle; modeling the atmosphere, forecasting the weather more accurately, supporting the telecommunication, monitoring tectonic movements in Turkey continuously, standing by the works on Pre-Earthquake Alerting Systems and determining transformation parameters (see 9 and 10).

\section{HORIZONTAL CONTROL NETWORK OF TURKEY}

Measurements such as horizontal direction, vertical angle, baseline and azimut angle were made for forming of first degree base triangulatinn network in between 1934-1950. A triangulation point where is in Meşe Dağ 1 was taken as starting point and all measurements were adjusted (Ersoy (1997)). As a result Turkey National Datum (TUD-54) was formed for horizontal control network (figure 1).

Then, this network was tied to the 8 common points where is in Bulgaria and Greece. So, the network datum was transformed to 1950 European Datum (ED-50). Coordinates of the points that formed horizontal control network of Turkey, were determined in ED-50. Coordinates of all the points of the network were calculated by using international Hayford Ellipsoid (Aktuğ et.all (2011)).

Parameter of the ellipsoid as below,

Semi major axes $a=6378388 \mathrm{~m}$

Semi minör axes $b=6356911.9461 \mathrm{~m}$

Flattening $\quad f=1 / 297$ 


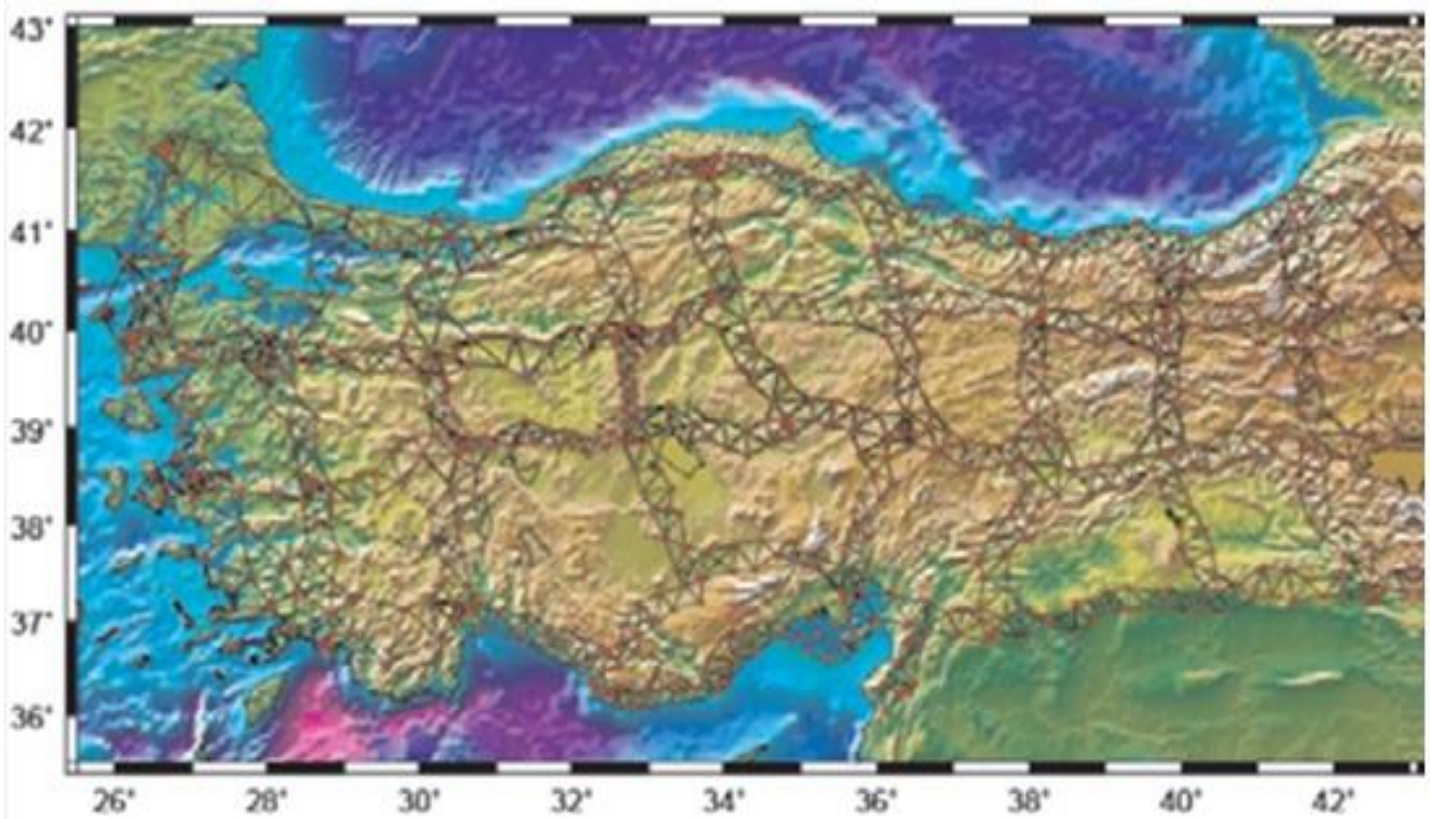

Figure 1 (Aktuğ et.all (2011)) : National Triangulation Network of Turkey

\section{VERTICAL CONTROL NETWORK OF TURKEY}

Geoid of Turkey (TC-91) was determined by using about 70000 gravite measurements that were made to determine heigts in between 1956-1991. National Vertical Control Network of Turkey (TUDKA-92) was formed by evaluating geometrical levelling measurements together with gravite measurements that were performed in every points of national network in 1936. Antalya mareograph station was taken as starting point in this work.

Current works on the determination of vertical datum was done according to the rapid improvements in satellite technologies, therefore GPS - leveling measurements were applied on TUDKA - 92 datum between 1988 and 1999; these measurements were integrated with Turkish Geoid (TG-91) and Turkish Geoid (TG-99) was created after having done the calculations on GRS80 ellipsoid which was determined by Geodesy and Geophysics Union in 1999 (figure 2).

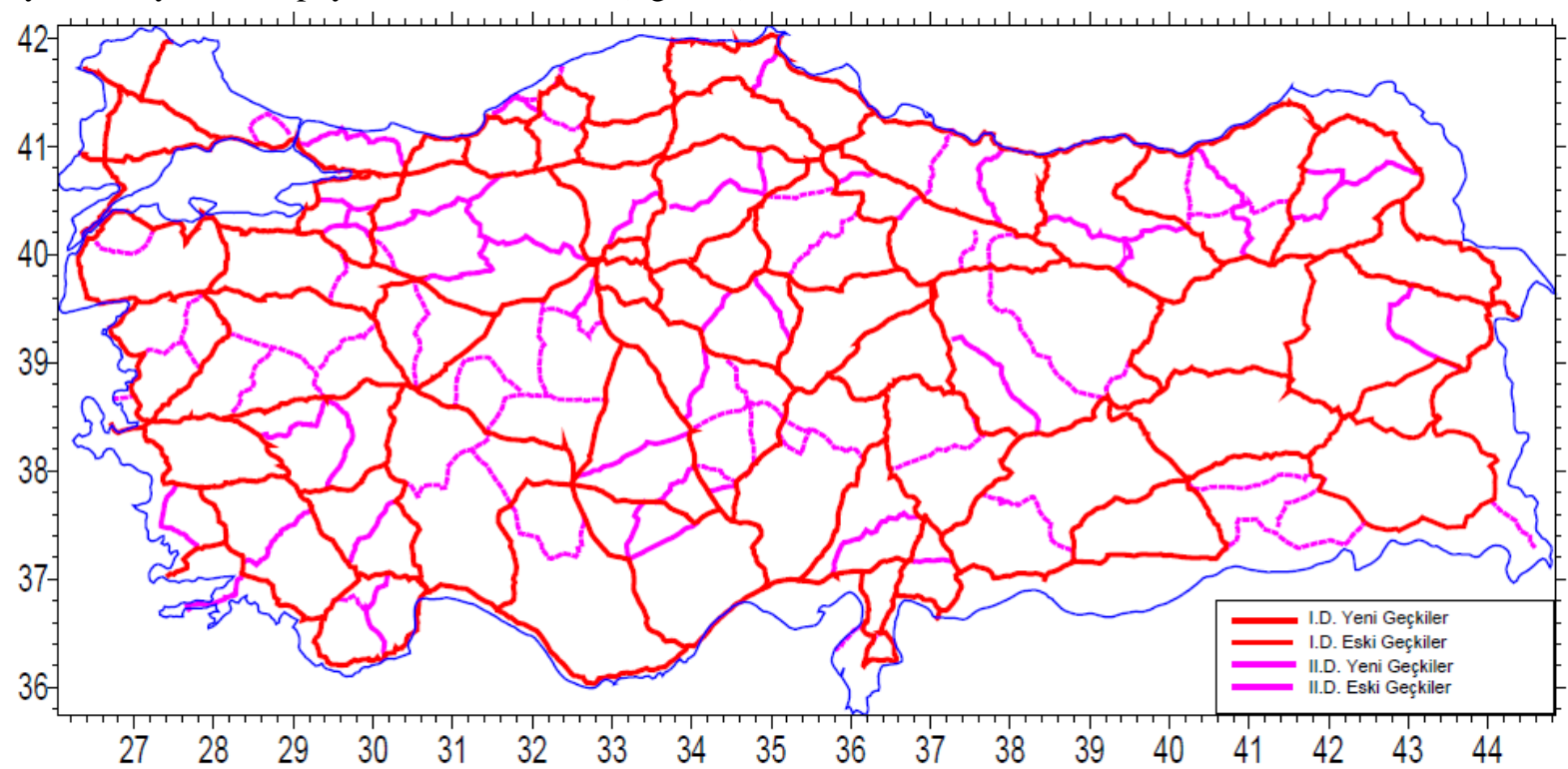

Figure 2 (Aktuğ et.all (2011)): National Vertical Control Network of Turkey 
Parameters of GRS80 Ellipsoid

Major semi-axis : $\mathrm{a}=6378137 \mathrm{~m}$

Minor semi-axis: $\mathrm{b}=6356752,31414 \mathrm{~m}$

Geometric Flattening: $f=1 / 298,2572221$

Hence, the coordinates of points which create Turkish Vertical Positional Network were obtained on GRS80 datum.

\section{DETERMINATION OF TURKISH TRIANGULATION NETWORK BY SATELLITE TECHNIQUES}

In order to obtain geometric and attribute data with modern techniques for the foundation of Geographical Information system not only in an accurate and reliable manner but also connected to national geodetic network, it is required to have a basic geodetic network that covers whole country with adequate frequency whose 3D coordinates were determined with expected accuracy. For this purpose, Turkish governmental agencies (Administration of Land Register and Cadastre \& General Commandership of Maps) prepared the project of Turkish National Basic GPS Network (TUTGA).

TUTGA Project, has started in 1997, is a static network for geodynamical purposes, that consists of 594 points (figure 3) which has a frequency of points of 15-70 km for IGS (International GPS Service) points depending on the national geoid changes and these points are connected to International Terrestrial Reference System (ITRF) calculating the coordinates (X, Y, Z) with an accuracy of some centimeters, velocity changes $(\mathrm{Vx}, \mathrm{Vy}, \mathrm{Vz})$, orthometric height $(\mathrm{H})$ and geoid height $(\mathrm{N})$.

Benefits of TUTGA

1) Acquisition of point coordinates more rapidly and more economically.

2) Acquisition of positional information for all purposes of navigation and vehicle monitoring

3) Determination of transformation parameters of Turkey.

4) Monitoring tectonic movements in Turkey and determination of deformations.

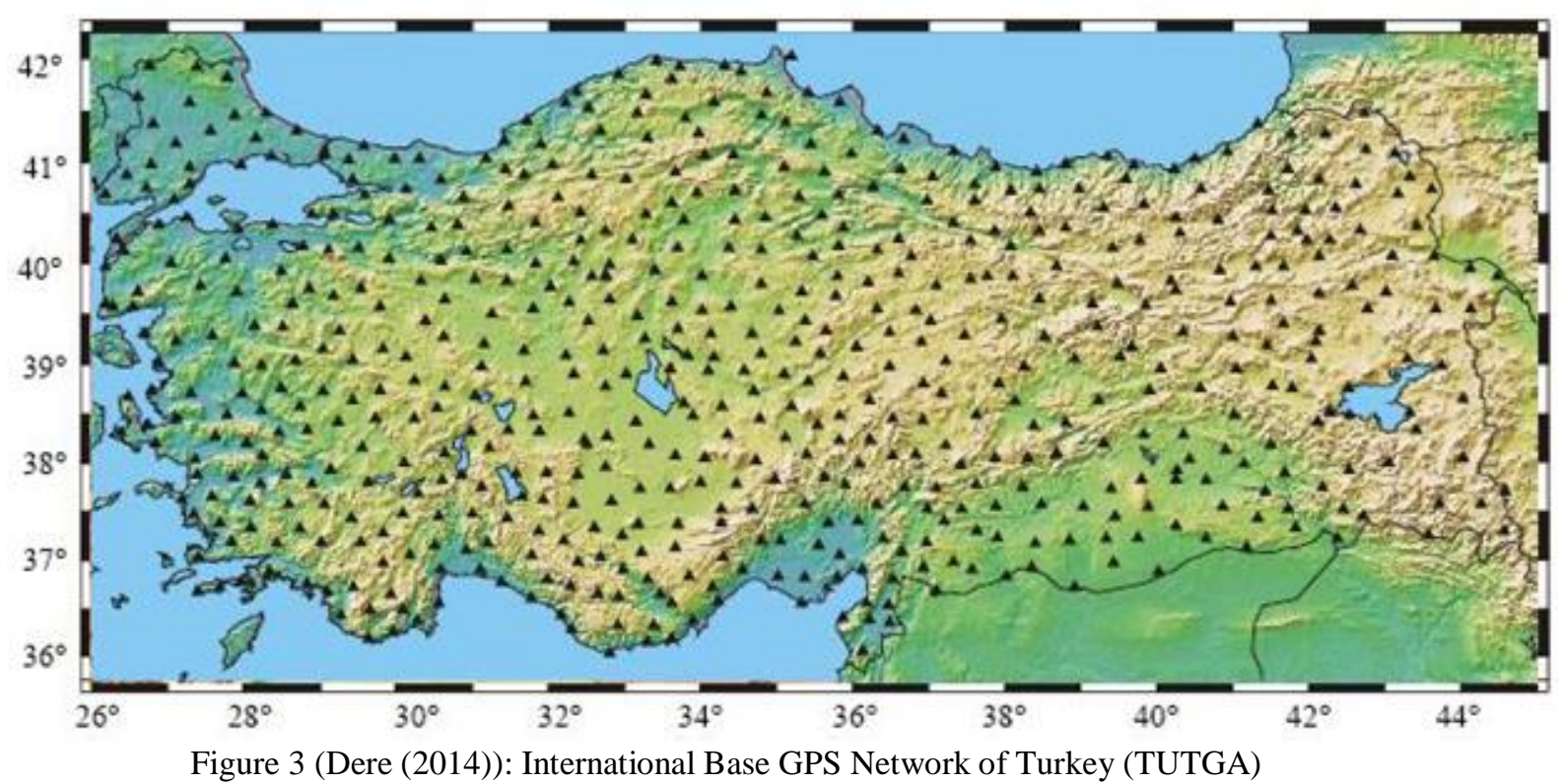

\section{CORS SYSTEM (Continuously Operating Reference Stations)}

In the United States, in order to achieve relative accuracy in centimeters in real time 3D positioning with GPS, CORS was established with continuously operating reference stations. CORS system is a network that consists of continuously operating GPS receivers across the country.

NGS is responsible for continuously collecting, processing and delivering the data in CORS stations.

NGS collects GPS data through the internet. Users can interpret with own GPS data with data by CORS via Online Positioning User Service (OPUS). 


\subsection{OPUS (Online Positioning User Service):}

It is service that enables GPS users to connect to National Spatial Reference System in a quick and easy manner.

In this service, GPS data is stored for more than 2 hours. They are added to NGS website in RINEX format and are interpreted by NGS' computers and software. Positional coordinates of points are obtained in couple of minutes (Yavuz et.all (2007)).

\section{TUSAGA-AKTIF / CORS-TR System}

Geographic data takes an important role in all types of spatial design, planning, applications and natural resources management in developed countries, especially in the US. By technological developments, Geographical/Urban Information Systems occurred with graphical and text data.

In order to supply reliable positional data for Cadastral, Mapping and GIS applications, governmental institutions like HGK, TÜBİTAK, TKGM and IKU set up a system TUSAGA-AKTIF/ CORS-TR that covers all Turkey for Real Time Kinematic ( RTK) applications after having started to use GNSS in Turkey.

TUSAGA -Aktif Project has been started in 2006. It is an active network that consists of 146 points which are connected to international IGS and ITRF systems. It enables to acquire high accurate coordinates with correction values anytime and anywhere in Turkey (Yıldirım et.all. (2009)).

The main purposes of CORS-TR system, which works in 7/24 time principle across Turkey, are:

1) Obtaining geographical coordinates rapidly and more economically for National GIS.

2) Determining accurate and reliable positions for navigation and vehicle-monitoring and delivering these data to users.

3) Determining cell transformation parameters by transformation of ED50-ITRFyy for Turkey.

4) Creating an atmospheric (troposphere and ionosphere) model for Turkey.

5) Monitoring tectonic plate movements in Turkey in a continuous and precise manner.

6) Supporting better meteorological forecasts and better scientific works like telecommunication.

On behalf of these purposes of CORS, it is possible to obtain cm-precision coordinate data economically in couple of minutes in anywhere in Turkey through e-government base for establishing spatial infrastructure.

\subsection{Components of CORS-TR System and Its Functions}

CORS-TR system consists of 4 components:

1) Global Navigation Satellite Systems (GNSS)

2) Control Stations

3) GNSS receivers

4) Telecommunication units

For determining the places where to put CORS-TR stations; soil features, electricity, telephone, internet and security are criteria and governmental lands were selected. Under these criteria, totally 146 stations were establishing covering all Turkey (Yıldırım et.all (2011), figure 4).

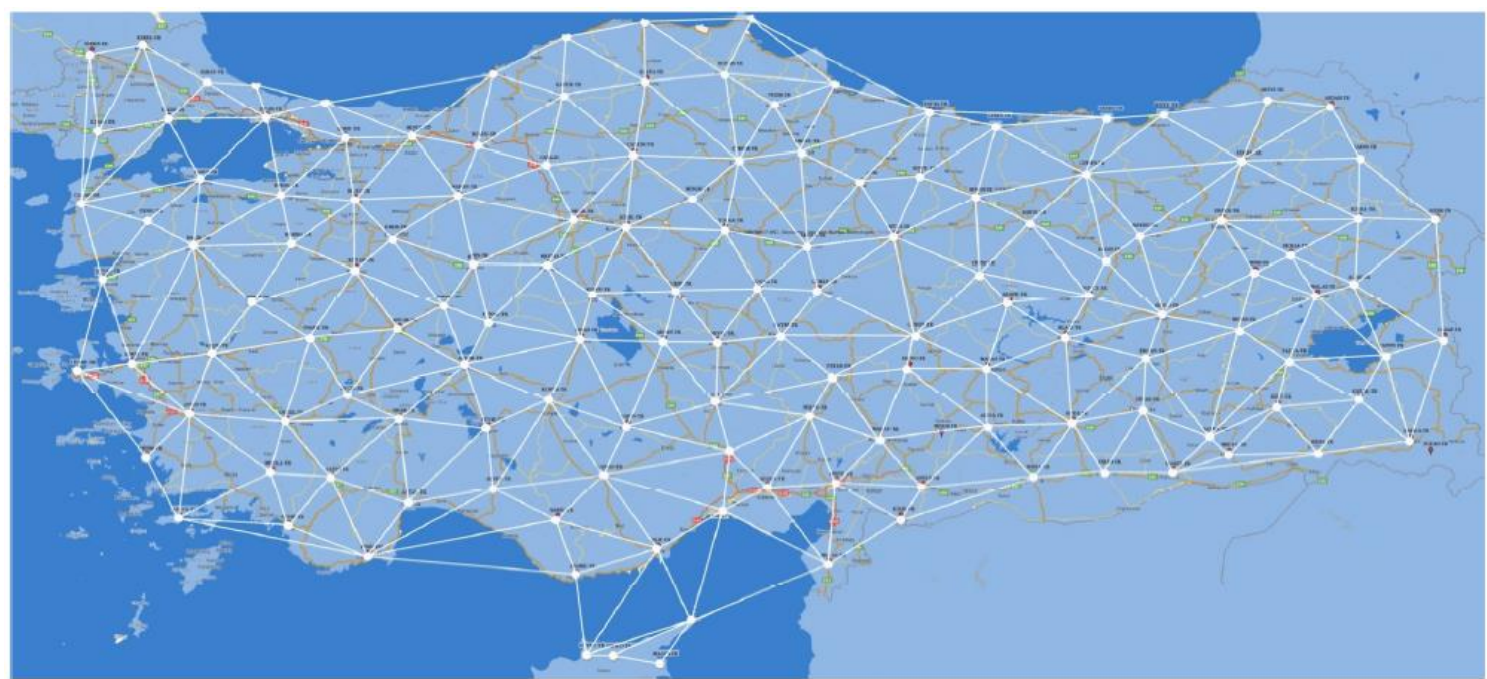

Figure 4 (Y1ldırım et.all (2011)) : Stations of CORS-TR (146 stations at 80-100 kilometer distances) 
In these stations, a receiver that co-works with GPS + GLONASS + GALILEO systems, ADSL/ GPRS modem, battery, lightning rod adapter, cable line protection, 4 fans with thermostat can be found in hardware cabin. In the exterior part of the cabin, there is a GNSS antenna that is connected to the receiver. The distribution of 146 stations' dimensions can be seen in figure 5 .
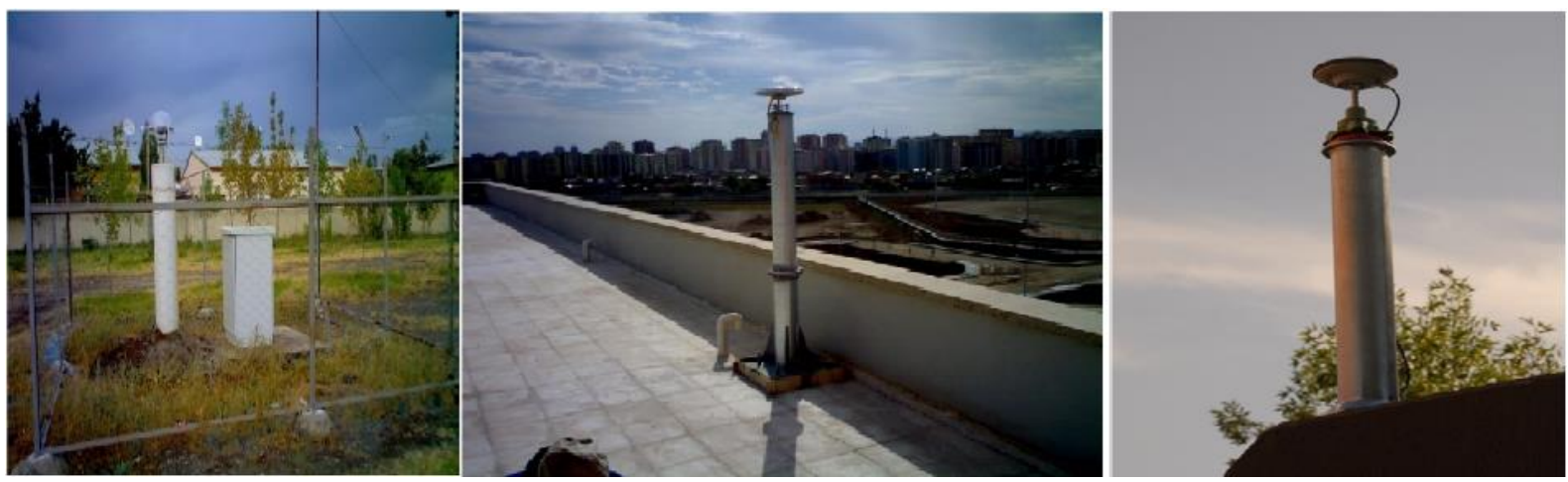

Figure 5 (Ylldırım et.all (2009)): Active Stations of CORS-TR in Turkey

There are two control stations one in TKGM, one in HGK) to interpret the collected data by CORS-TR stations (figure 6). The communication between these control stations and permanent stations is done by internet-based ADSL and GPRS/EDGE in 365 days/24 hours. The data transfer between control station and rovers (users) is developed by German Geodesy and Cartography Institute (BKG) and is supplied with NTRIP format.
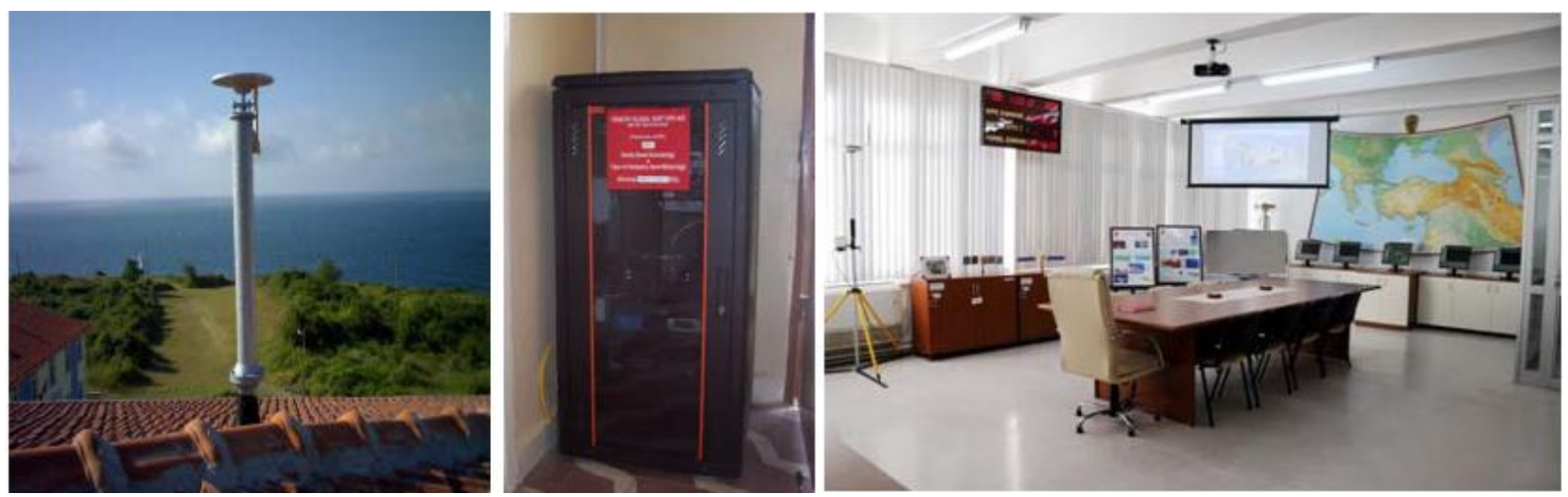

Figure 6 (Yıldırım et.all (2009)) : HGK Control Analaysis Center

Data interpretation is done by Trimble VRS SW software in control stations. This software consists of GPS Net, RTK Net, Webserver, Rover Interpret, Coordinate Monitor and Data Storage Monitor modules. The correction parameters that are calculated in control stations are delivered to users (rovers) instantaneously. Hence, positions of points (coordinates) are obtained in real time. In parallel, active users that enjoy this system are followed in control stations (Yildirım et.all (2009), figure 4).

The functions in control stations:

1) Calculating real time coordinates of rovers.

2) Controlling CORS-TR stations and orienting the users.

3) Downloading and storing real time GNSS measurements.

4) Analyzing CORS-TR network in high precision with Post-processing.

5) Modeling troposphere and ionosphere in the atmosphere for Turkey.

6) Calculating correction values for purposes of RTK positioning.

7) Broadcasting real time data and correction values in NTRIP format.

8) Supplying web service.

Communication and functions among control station, reference station and users are shown in Figure 7. 


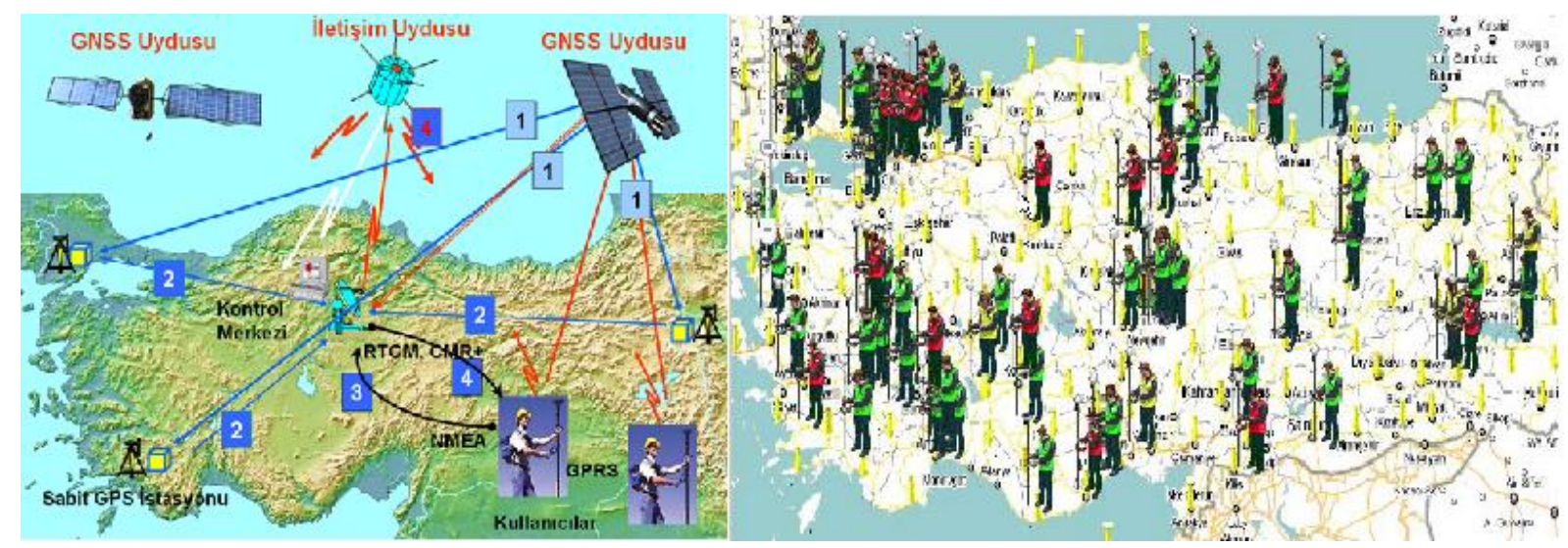

Figure 7 (Yıldırım et.all (2009-2011)) : Communication Between Control Centers and Users

\section{Conclusions}

By 2011, approximately more than 4000 users utilize CORS-TR system. Because of CORS-TR system, cadastral and geodetic works across Turkey are done without the necessity of local reference points and in a rapid and economic way. Because of the establishment of CORS-TR system, Turkey saves up to approximately 35 million US dollars.

\section{References}

[1] Aktuğ, B., et al. (2011) Datum Transformation between ED-50 (European Datum-1950) and TUREF (Turkish National Reference Frame), Harita Genel Komutanlığı, Ankara

[2] Eren, K., et.all. (2009) Results from a Comprehensive Global NavigationSatellite System Test in the CORS-TR Network: Case Study. J. Surv. Eng., 135(1), 10-18.

[3] Ersoy, N., (1997), İstanbul Nirengi Çalışmalarının Yersel ve GPS ölçüleri İle Değerlendirilmesi ve Analizi, Phd Thesis.

[4] İKÜ, (2010), TUSAGA AKTİF (CORS-TR) Projesi, Sonuç Raporu, TUBİTAK Proje No: 105G017, Temmuz.

[5] Yavuz, E., Ersoy, N, (2007), Amerika Birleşik Devletlerindeki CORS programi, 11. Türkiye Haria Bilimsel ve Teknik Kurultayı, 2-6, ODTÜ-Ankara

[6] Yıldırım Ö; et.all, (2009), TUSAGA-Aktif (CORS-TR), 4.Mühendislik Ölçmeleri Sempozyumu, Trabzon.

[7] Yildirim. Ö, et.all (2011), TUSAGA-AKTİF (CORS-TR) Sisteminin Tapu ve Kadastro Genel Müdürlüğüne

Katkilari,

TMMOB Harita ve

Kadastro Mühendisleri Odası 13. Türkiye Harita Bilimsel ve Teknik Kurultayı 18-22, Ankara.

[8] http://geomatik.beun.edu.tr/kemaldere/files/2014/03/jdf242_jeo_olc_3.hafta_.pdf

[9] http://www.hgk.msb.gov.tr/haritalar_projeler/bildiriler/jeodezi/makale(pdf)/jeo_tek_bil5.pdf

[10] http://www.hgk.msb.gov.tr/haritalar_projeler/jeodezi/TUSAGA_Aktif_Genel_Bilgi_internete.p df. 